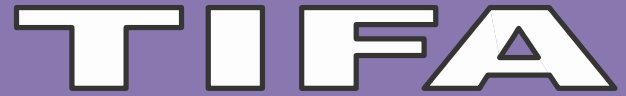
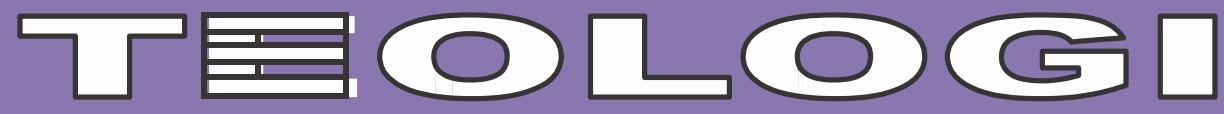

\section{JURNAL PROGRAM PASCASARJANA TEOLOGI}

Agustinus 0. Lopuhaa, M.Th

HUNAJEWE

Konsep Tuhan Bagi Masyarakat Makatian

Corneli Bakarbessy, M. Th

Bawakat: Berteologi Ekofeminis Dalam Konteks Perempuan Aru

Di Desa Rebi

Theresia H. A. Effendy, M.Th

Alam sebagai saudara:

Berteologi dari Kosmologi Orang Hukurila

Astina Iwamony/U, M.Th

GPM DAN IM

Henky H. Hetharia, M. Th

Korupsi Dalam Perspektif Etika Kristen

Johan Saimima, S.Si, M.A.

Identitas Postkolonial Dalam Konteks Masyarakat Maluku:

Studi Teologi Pembebasan 


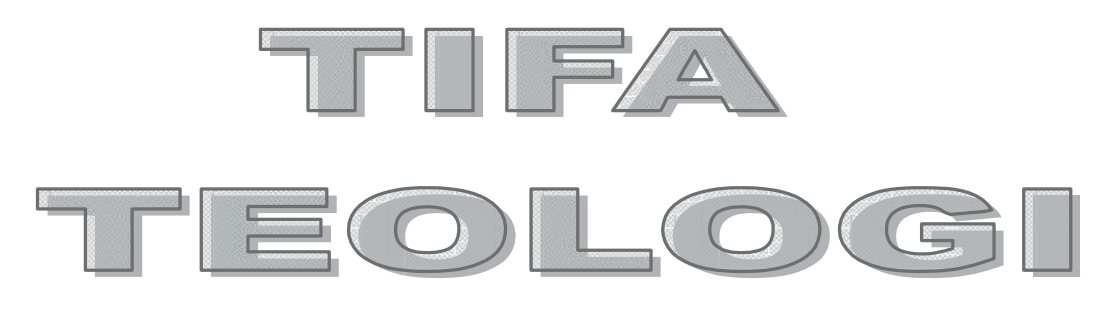

JURNAL PROGRAM PASCASARJANA TEOLOGI

UNIVERSITAS KRISTEN INDONESIA MALUKU

Dewan Redaksi

PENASEHAT : DR. I.W.J. HENDRIKS

KETUA : RACHEL IWAMONY-TIWERY, PH.D

SEKRETARIS : MATALSEA TAMAELA, S.Si

BENDAHARA : N. RALAHALU-RUHULESSIN

ANGGOTA : DR. M.M. HENDRIKS-RIRIMASSE

DR. H. TALAWAY

DR. C.A. ALYONA

DR. E. CHR. MARANTIKA-MAILOA

DR. A.M.L. BATLAJERY

DR. E. PATTINAMA-TAHAPARY

LEMBAGA MITRA

DRS. S.J. PATTY (MOLUKS EVANGELISCHE KERK-GIM)-Houten DRS. S. RIRIHENA (MOLUKS THEOLOGY BERAAD-MTB)-Houten ALAMAT REDAKSI

Kantor dan Alamat Surat:

Program Pascasarjana Teologi Agama dan KebudayaanUKIM

Kampus UKIM, Jl.Ot. Pattimaipauw, Talake-Ambon

(0911) 351642

Email: tifateologi@yahoo.co.id 


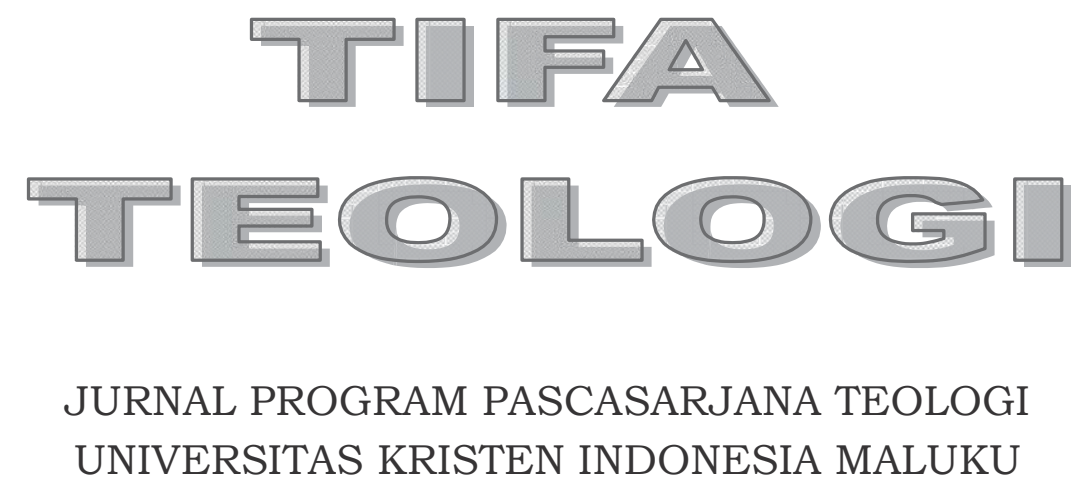

\section{DAFTAR ISI}

\section{Pengantar Dari Redaksi}

\section{Agustinus 0. Lopuhaa, M.Th}

HUNAJEWE

Konsep Tuhan Bagi Masyarakat Makatian

Corneli Bakarbessy, M. Th

Bawakat

Berteologi Ekofeminis Dalam Konteks Perempuan Aru Di Desa Rebi

Theresia H. A. Effendy, M.Th

Alam Sebagai Saudara

Berteologi dari Kosmologi Orang Hukurila

Astina Iwamony/U, M.Th

GPM DAN IM

Henky H. Hetharia, M. Th

Korupsi Dalam Perspektif Etika Kristen

Johan Saimima, S.Si, M.A.

Identitas Postkolonial Dalam Konteks Masyarakat Maluku

Studi Teologi Pembebasan 



\title{
KORUPSI DALAM PERSPEKTIF ETIKA KRISTEN
}

\section{Henky H. Hetharia, M.Th}

\begin{abstract}
"Sebab Tuhan, Allahmulah Allah segala allah dan Tuhan segala tuhan, Allah yang besar, kuat dan dasyat, yang tidak memandang bulu ataupun menerima suap" (Ul. 10:17).
\end{abstract}

\section{ABSTRACT}

Corruption behavior has become a society apprehension globally and nationally in Indonesia. The apprehension has motivated people to prevent and overcome the corruption practices. Corruption is not only a social matter but also a theological matter, especially, dealing with ethics and moral. Corruption may happen because of external factors (opportunities) and internal factors (intentions). Ethically, the corruption behavior is stimulated by internal factors of the corruptors who have intentions of their human needs. This writing is going to highlight the corruption behavior on the Christian Ethics perspectives. The human intentions and motivation as the internal factors of the corruption behavior will be considered and valued based on Christian Ethics. The values of Christian Ethics, which are from the Bible as the source of Christianity values, and theologians perspectives on the corruption behavior will be offered, so that we will understand and respond the corruption behavior well based on Christian faith.

Key Word: Corruption, behavior, Ethics

\section{Pendahuluan}

Perilaku korupsi yang marak terjadi hingga saat ini, merupakan suatu fenomena multi-aspek kemasyarakatan, baik aspek sosial, ekonomi, budaya, politik, hukum, termasuk aspek keagamaan (moral/etika). Aspek-aspek tersebut harus diperhatikan dalam upaya memberantas persoalan korupsi yang telah menjadi penyakit bahkan telah dianggap sebagai budaya dalam masyarakat Indonesia secara nasional (Mochtar Lubis dalam Lubis dan Stott (ed.), 1988: xvii - xx).

Korupsi telah menjadi masalah global, sehingga tak kurang dari badan PBB telah bereaksi terhadapnya dengan mengesahkan Konvensi PBB untuk Melawan Korupsi (United Nations Convention Against Corruption, UNCAC) di New York, pada 9 Desember 2003, yang kemudian ditetapkan sebagai Hari Pemberantasan Korupsi Sedunia. Konvensi PBB ini kemudian ditindaklanjuti oleh semua negara termasuk Indonesia, dengan merumuskan sejumlah peraturan dan membentuk badan-badan yang berhubungan dengan upaya pemberantasan korupsi, termasuk pencanangan Gerakan Nasional Pemberantasan Korupsi pada 9 Desember 2004 oleh Presiden RI Susilo Bambang Yudhoyono. Gerakan ini ditempuh pemerintah untuk memberantas korupsi yang telah mewabah dan membudaya dalam berbagai lapisan masyarakat.

Sebegitu parahnya korupsi dalam masyarakat Indonesia, sehingga Departemen Agama sebagai lembaga yang mengurusi bidang keagamaan (moral) di Indonesia juga tak luput dari persoalan korupsi ini (Ingat kasus korupsi yang melibatkan mantan Menteri Agama RI (Said Agil Husein Al Munawar). Karena itu, tidaklah mengherankan kalau lembaga Transparency International (TI) menempatkan Indonesia sebagai salah satu negara terkorup di dunia (hal ini ditegaskan dalam sambutan Ketua Komisi Pemberantasan Korupsi RI pada pencanangan tahun 2005 sebagai tahun dimulainya Ger- 
akan Nasional Pemberantasan Korupsi, bahwa sampai dengan bulan Oktober 2004, hasil survey yang dilakukan oleh Lembaga Transparency International yang berbasis di Berlin-Jerman menempatkan Indonesia pada urutan ke-5 negara-negara yang paling korup di dunia, atau berada pada ranking ke-137 dengan Indeks Persepsi Korupsi (IPK) 2,0: Perum PNRI, 2004: xiv). Pada (Desember) 2011, hasil survey lembaga ini menempatkan Indonesia pada urutan ke 100 dari 183 negara di dunia dengan IPK 3,0. Hal ini cukup melegakkan kita karena Indonesia dinilai telah mengalami peningkatan dalam upaya pemberantas korupsi. Walaupun demikian kita masih melihat maraknya kasuskasus korupsi pada skala masif di Indonesia akhir-akhir ini, yang melibatkan berbagai pihak baik eksekutif, legislatif, yudikatif, partai politik, dan sebagainya dan terjadi pada hampir seluruh jenjang pemerintahan dan masyarakat. Karena itu, tak heran jika Presiden RI, Susilo Bambang Yudhoyono sendiri menegaskan bahwa korupsi telah menjadi suatu kejahatan yang luar biasa (ekstra ordinary crime) di negara ini.

Telah disebutkan di atas bahwa salah satu aspek yang langsung berhubungan dengan perilaku korupsi adalah aspek keagamaan (moral/etika), di mana aspek ini sangat mempengaruhi sikap seseorang terhadap praktek korupsi. Hal ini sejalan dengan pendapat seorang pembaharu Cina di masa lampau, Wang An Shih (1021-1086), yang menyebut adanya dua sumber korupsi: buruknya hukum dan buruknya moral manusia (Alatas, 1983:7-8). Pentingnya aspek moral (etika) seperti yang ditekankan oleh Wang An Shih tersebut akan menjadi fokus tulisan ini, di mana persoalan korupsi tersebut akan ditinjau dari perspektif Etika Kristen. Tulisan ini akan diawali dengan meninjau secara singkat hal-hal di seputar permasalahan korupsi, antara lain: pengertian, faktorfaktor penyebab, isme-isme yang mempengaruhi korupsi, akibat, dan diakhiri dengan pembahasan tentang perspektif Etika Kristen terhadap perilaku korupsi dimaksud.

\section{Masalah Korupsi}

\section{Pengertian.}

Istilah Korupsi berasal dari bahasa Latin, corruptio atau corruptionis yang berarti: hal merusak atau hal membuat busuk, pembusukan, penyuapan. Kata latin ini kemudian digunakan juga dalam bahasa Inggris (corrupt, corruption), dan bahasa Indonesia (korup, korupsi). Dalam Kamus Besar Bahasa Indonesia (2005:596), korup (kata sifat) berarti: buruk, rusak, busuk; atau suka memakai barang (uang) yang dipercayakan kepadanya, dapat disogok (memakai kekuasaannya untuk kepentingan pribadi). Sedangkan korupsi (kata benda) yaitu: penyelewengan atau penyalahgunaan uang negara (perusahan, dsb) untuk kepentingan pribadi atau orang lain. Robert Klitgaard (2001:31) menilai kata korupsi ini menimbulkan serangkaian gambaran yang jahat; kata ini berarti apa saja yang merusak keutuhan. Ia melihat bahwa ada dimensi moral pada kata tersebut, di mana tindakan korupsi berhubungan dengan moral pelakunya (ini sejalan dengan pendapat Wang An Shih seperti disebutkan di depan). Alatas (1987:225), juga menyimpulkan bahwa inti korupsi adalah perwujudan immoral dari dorongan untuk memperoleh sesuatu dengan metode pencurian dan penipuan.

\section{Faktor-faktor Penyebab.}

Amrizal (dalam jurnal Equilibrium, 2004:62-63), menyimpulkan hampir semua riset menyatakan bahwa sebab-sebab korupsi merupakan sebuah gejala dari kelemahan institusional yang mendalam, suatu gejala dari kelemahan fundamental negara. Ia 
mengutip pendapat Vinod Thomas dkk, yang secara lebih spesifik menawarkan faktorfaktor penyebab korupsi dalam negara, yaitu:

1. Ketiadaan hak politik dan kebebasan sipil. Hak-hak politik, yang mencakup pemilihan umum yang demokratis, badan legislatif dan partai-partai oposisi, serta kebebasan sipil yang mencakup hak-hak atas media yang bebas dan independen dan kebebasan berserikat serta berpendapat secara negatif berkorelasi dengan korupsi.

2. Keuangan publik dan regulasi. Korupsi ternyata lebih tinggi terjadi di negara-negara di mana terdapat tingkat kepemilikan yang tinggi oleh negara dalam ekonomi, regulasi bisnis dan pajak-pajak yang berlebihan (execive tax), penerapan regulasi secara sewenang-wenang serta adanya restriksi perdagangan. Pola ekonomi yang monopolistik juga cenderung memiliki tingkat korupsi yang tinggi.

3. Pegawai Negeri. Profesionalisme pegawai negeri, yang mencakup perekrutan, pelatihan dan sistem promosi juga terkait dengan tingkat korupsi yang lebih rendah.

4. Penyalahgunaan kekuatan militer. Yoshihara Kunio (seorang ekonom Jepang) berpendapat pembagian kekuasaan di antara para pemimpin militer di Indonesia "memungkinkan para pemimpin militer menggunakan kekuatan politik untuk berbagai macam kepentingan dan dalam lapangan ekonomi, menciptakan kroni serta sejumlah besar pemburu keuntungan".

5. Inefisiensi birokrasi (inefficient bureaucracy). Augusto Lopes-Claros, Chief Economist Director world Economic Forum's Global Competitiveness Programme menyatakan salah satu sebab tingkat korupsi yang tinggi di Indonesia adalah panjangnya jalur birokrasi yang harus dilalui. Panjangnya alur perijinan investasi di lembaga pemerintahan memberi peluang terjadinya korupsi.

6. Sistem Intensif (incentive system). Teori ekonomi regulasi mengatakan bahwa 'korupsi, kolusi dan mencari rente' dapat menjadi pilihan yang optimal bagi individu pengusaha/birokrasi/legislator jika sistem yang ada memang mengarahkan ke situ.

7. Tidak adanya political will dari pihak eksekutif dan legislatif. Ketiadaan political will dari pihak eksekutif dan legislatif dapat menciptakan kondisi yang menyuburkan praktek-praktek korupsi. Karena itu, political will tersebut sangat diperlukan guna memberantas kasus-kasus korupsi khususnya di Indonesia.

Memang ada banyak perumusan tentang faktor-faktor penyebab korupsi ini (Alatas, 1987:120; Lubis dan Scott (ed.) 1995: xiii-xvi; Robert Klitgaard, dkk, 2002: 37-38). Namun dari pemaparan di atas, apa yang dikemukakan oleh Vinod Thomas dkk dapat menjadi gambaran bagi kita tentang faktor-faktor penyebab korupsi tersebut. Kita lalu dapat menyimpulkan bahwa korupsi dapat terjadi karena ada begitu banyak peluang dan kesempatan serta berbagai sistem yang berlaku dalam negara/masyarakat yang memungkinkan terjadinya praktek korupsi. Seseorang melakukan korupsi karena adanya peluang dan kesempatan bagi orang tersebut untuk melakukannya, yang dimungkinkan oleh adanya sistem-sistem yang berlaku.

\section{Isme-isme yang mempengaruhi korupsi.}

Korupsi selain merupakan sebuah gejala dari kelemahan institusional (peluang) seperti yang disebutkan di atas, juga sangat dipengaruhi oleh budaya masyarakat kita 
dewasa ini. F.X. Didik Bagiyowinadi, Pr (2003:14-17) mengemukakan beberapa isme dalam mentalitas zaman modern yang ikut membentuk budaya korupsi:

1. Konsumerisme. Konsumerisme adalah kecenderungan mengkonsumsi apa yang ditawarkan pasar, tanpa mempertimbangkan apakah hal itu sungguh dibutuhkan, penting, dan berguna, ataukah tidak. Sikap ini tentu akan mendorong niat seseorang untuk melakukan korupsi.

2. Egoisme. Egoisme yang tidak sehat berarti pandangan atau sikap hidup yang mendewakan pemenuhan kebutuhan ego dan penghargaannya, sehingga akan mendorong seseorang menjadi rakus dan serakah, dan akan melahirkan budaya korup karena orang lebih mencari pemenuhan kebutuhannya sendiri daripada kebutuhan masyarakat atau publik.

3. Instantisme. Instantisme adalah sikap yang menuntut segala sesuatu yang dimaui ada seketika, pemenuhan kebutuhan dengan jalan pintas. Instantisme yang diterapkan pada pemenuhan kebutuhan materi, sementara pendapatan seseorang tidak mencukupi, akan mendorong orang tersebut melakukan tindakan korupsi.

4. Formalisme. Formalisme adalah sikap yang lebih mementingkan bentuk, ungkapan, rumusan dan huruf-huruf yang menyatakannya daripada isi dan maksud yang hendak dinyatakan, isinya kosong dan tidak bermutu. Contohnya, pemborong yang membuat bangunan yang bagus-bagus namun tidak lama sudah runtuh karena bahannya tidak berkualitas. Sikap ini sarat dengan praktek korupsi.

5. Sekularisme. Sekularisme adalah sikap hidup yang memisahkan antara kehidupan duniawi dan kehidupan rohani. Seorang sekularis hanya merasa sebagai seorang yang beragama hanya sewaktu ia ada dalam aktivitas keagamaan, lepas dari itu ia kembali ke dunia dan mengikuti hukum-hukum dunia lagi. Dalam hal ini, imannya sama sekali tidak berbicara dalam kehidupannya sehari-hari. Karena itu, berbagai tindakan duniawi termasuk korupsi dianggap wajar dan dapat saja dilakukan.

Dari penjelasan di atas, jelaslah bahwa korupsi juga dapat terjadi karena adanya sejumlah isme atau sikap hidup, mentalitas zaman moderen yang turut mempengaruhi dan mendorong niat/keinginan seseorang untuk melakukan praktek korupsi tersebut. Dengan demikian, dapat disimpulkan bahwa perilaku korupsi terjadi tidak saja karena adanya peluang dan kesempatan, tetapi juga karena adanya niat/keinginan yang timbul oleh karena didorong oleh berbagai mentalitas (isme) zaman moderen.

Akibat.

Umumnya diakui bahwa tindakan korupsi membawa akibat yang buruk dan merusak bagi suatu negara. Amrizal (Equilibrium; 2004:64-66) mengemukakan beberapa implikasi korupsi, baik terhadap perekonomian negara maupun terhadap sosialpolitiknya, yang bisa menjadi gambaran bagi kita tentang akibat buruk dari tindakan korupsi tersebut, yaitu:

1. Melemahnya kepercayaan investor.

2. Alokasi pengeluaran pemerintah yang tidak tepat.

3. Terhadap pembangunan berkelanjutan.

4. Terhadap kaum miskin. 


\section{Terhadap perniagaan dan pengaruh korporat terhadap pemerintah nasional.}

Robert Klitgaard (2001:60), setelah menganalisa berbagai akibat buruk dari korupsi, menyimpulkan bahwa korupsi umumnya merugikan pembangunan ekonomi, politik dan organisasi. Akibat korupsi, juga pernah ditegaskan oleh Presiden RI (Susilo Bambang Yudhoyono), bahwa "Korupsi yang selama ini terjadi secara meluas, tidak hanya merugikan keuangan negara, tetapi juga telah merupakan pelanggaran terhadap hak-hak sosial dan ekonomi masyarakat secara luas" (Hal ini ditegaskan oleh Presiden RI dalam sambutannya pada Pencanangan Gerakan Nasional Pemberantasan Korupsi pada tanggal 9 Desember 2004 di Istana Negara Jakarta, yang ditandai dengan dikeluarkannya Instruksi Presiden (INPRES) RI Nomor 5 tahun 2004 tentang Percepatan Pemberantasan Korupsi , 2004: viii).

Akibat buruk dari perilaku korupsi ini mengharuskan semua elemen masyarakat untuk memeranginya, termasuk gereja. Gereja terpanggil untuk terlibat secara positif, kreatif, kritis dan realistis, menjalankan perannya di tengah-tengah negara kesatuan Republik Indonesia yang berdasarkan Pancasila. Perannya ini dengan berbagai tantangan dan pergumulannya, dilaksanakan dengan penuh tanggung jawab berdasarkan tugas dan panggilan yang bersumber pada Injil Yesus Kristus (Weinata, 1996:3). Kita lalu teringat akan pemikiran DR. T.B. Simatupang tentang peran serta Gereja dan Agama-Agama untuk meletakkan landasan Etik, Moral, dan Spiritual bagi para pemeluknya dalam mengisi Pembangunan Nasional sebagai Pengamalan Pancasila. Gereja sangat bertanggung jawab dalam membina dan meningkatkan kehidupan etik, moral, dan spiritual warganya, untuk menghasilkan warga negara yang bermoral tinggi (istilah Wang An Shih) yang dapat mengontrol dirinya, mencegah dan tidak tergoda untuk melakukan praktek korupsi.

\section{Korupsi dalam Perspektif Etika Kristen.}

Perilaku korupsi sebagai masalah sosial, patut mendapat penilaian etika Kristen. Hal ini tidak saja disebabkan oleh tanggung jawab etika untuk memberikan penilaian normatif terhadap masalah-masalah sosial, tetapi lebih dari itu perilaku korupsi merupakan masalah yang berhubungan langsung dengan masalah etika, faktor buruknya moral pelaku sebagai faktor internal. Faktor internal ini tentu menjadi tanggung jawab etika (Kristen) untuk memberikan penilaian normatif terhadapnya. Melalui penilaian normatif ini, manusia dapat mengetahui apa yang seharusnya (what ought to) ia perbuat sehubungan dengan perilaku korupsi tersebut. Etika Kristen memberikan penilaian tentang baik atau buruknya perilaku korupsi menurut pengajaran iman Kristen, sehingga manusia khususnya orang Kristen memahaminya secara sadar dan menentukan sikap terhadap praktik korupsi tersebut. Untuk maksud ini, pertama-tama kita akan melihat perilaku korupsi dalam perspektif Alkitab (Perjanjian Lama dan Perjanjian Baru) yang merupakan sumber nilai dan norma etika (moral) kekristenan, kemudian dilanjutkan dengan pandangan para teolog terhadap perilaku korupsi tersebut.

Istilah Korupsi memang tidak terdapat atau tidak dikenal dalam Alkitab (dunia PL dan PB) sebab memang istilah korupsi bukanlah merupakan istilah khas dalam bahasa Ibrani (PL) maupun bahasa Yunani (PB). Namun, bukan berarti bahwa masalah korupsi tersebut tidak terjadi atau tidak mendapat perhatian dalam Alkitab. Masalah korupsi banyak diungkapkan dan mendapat perhatian dalam peristilahan yang lain dalam Alkitab seperti yang akan kita lihat berikut ini: 
Dalam Perjanjian Lama (PL), istilah yang paling sering dipakai untuk menggambarkan praktek korupsi tersebut adalah: suap atau sogok (Ibr.: שש, shd, Ing.: bribe, bribery). Suap atau sogok ini merupakan tindakan korupsi, sama dengan korupsi (Heidenheimer dalam Lubis dan Scott, 1993:1). Dalam kehidupan umat Israel, masalah korupsi (suap, sogok) sangat sering terjadi dan banyak mendapat sorotan dan kritik para nabi. Sama halnya dengan bangsa-bangsa lain di dunia, Israel sebagai suatu persekutuan umat/bangsa tidak terlepas dari praktek korupsi (Alatas (1987:1). Kita akan menelusuri masalah korupsi ini secara khusus dalam sejarah Israel (Ibrani), sebagaimana yang tertulis dalam Alkitab. Seperti yang dapat kita baca di dalam kitab Keluaran 23:8 "suap janganlah kau terima, sebab suap membuat buta mata orang-orang yang melihat dan memutarbalikan perkara orang-orang yang benar". R.A. Knox sebagaimana yang dikutip oleh Alatas (1987:2) mengartikan ayat ini sebagai berikut "Waspadalah terhadap uang suap; uang suap dapat membutakan mata orang, walaupun ia seorang yang bijaksana dan hati-hati, dan mengusik keputusan, walaupun ia orang yang adil". Itu berarti bahwa ayat ini hendak memperingatkan Israel tentang akibat buruk dari praktek suap, yaitu dapat membutakan seseorang terhadap keadilan dan kebenaran. Karena itu, umat Israel diperingatkan untuk tidak menerima suap, khususnya para hakim dan tua-tua Israel dalam melaksanakan proses peradilan secara adil. Christopher Wright (1993:161), menilai ayat ini dan bahan-bahan lainnya dalam PL yang berbicara tentang hukum kebajikan, mempunyai sifat praktis yaitu perikemanusiaan (sosial), tetapi asal mula dan motifnya bersifat teologis, dan dari sudut pandang etis itulah yang paling penting. Ayat ini (Kel.23:8) termasuk dalam kumpulan 'Kitab Perjanjian' (Kel.20:2223:33), yang secara historis umumnya disepakati sebagai kumpulan hukum yang paling tua dalam PL (Wright, 1993:154).

Dalam Kitab Ulangan, peringatan tentang suap ini juga sangat kuat. Ul. 10:17 menegaskan: "sebab Tuhan, Allahmulah Allah segala allah dan Tuhan segala tuhan, Allah yang besar, kuat dan dasyat, yang tidak memandang bulu ataupun menerima suap". Menarik bahwa dalam ayat ini, suap dihubungkan dengan karakter Allah yaitu tidak menerima suap. Suap bukannya saja persoalan manusia, tetapi juga berhubungan dengan Tuhan Allah yang menentang praktek tersebut. Itu berarti bahwa PL menentang praktek suap bukan hanya karena alasan sosial (dimana suap merugikan banyak orang) tetapi terlebih karena alasan teologis, di mana Allah tidak melakukan tindakan tersebut, menentangnya dan karena itu Allah menghendaki Israel untuk juga tidak melakukannya. PL menentang praktek suap dengan bersumber pada karakter dan kehendak Allah. Hal ini sebagaimana yang disimpulkan oleh Bruce C. Birch (1991:37), bahwa sumber moral (termasuk hukum) dalam PL berfokus pada Allah. Allah (kehendak, aktivitas dan karakterNya) adalah sumber dan dasar moralitas dalam PL. Juga dalam Ul. 16:19, berisikan larangan menerima suap: “Janganlah memutarbalikan keadilan, janganlah memandang bulu dan janganlah menerima suap, sebab suap membuat buta mata orang-orang bijaksana dan memutarbalikan perkataan orang-orang yang benar". Teks ini mirip dengan Kel. 23:8 di atas. Teks lain yang dapat kita baca tentang larangan menerima suap juga di dalam Im. 19:15; II Taw.19:7. Wright (1993:175) menilai bahwa teks-teks ini menunjukan betapa prihatinnya PL akan cara pelaksanaan hukum yang seharusnya sesuai dengan isi hukum itu sendiri. Rupanya keprihatinan PL ini muncul karena para pelaksana hukum/peradilan tidak melaksanakan fungsinya secara benar dikarenakan oleh praktek suap yang sering terjadi dan mempengaruhi proses pera- 
dilan sehingga hukum dan kebenaran/keadilan tidak dapat ditegakkan sebagaimana mestinya.

Sebelum Israel menjadi sebuah kerajaan, khususnya sewaktu mereka di bawah kepemimpinan hakim-hakim, persoalan suap telah terjadi dan merajalela di dalam kehidupan umat Israel, khususnya di kalangan para hakim yang melakukan proses peradilan. Persoalan suap tersebut nampaknya sangat memprihatinkan sehingga anak-anak Samuel yang diangkat menjadi hakim atas orang Israel (I Sam.8:1,2), juga tak luput dari persoalan suap tersebut. Dalam I Sam. 8:3, disebutkan bahwa "Tetapi anak-anaknya itu tidak hidup seperti ayahnya; mereka mengejar laba, menerima suap dan memutarbalikkan keadilan". Rupanya persoalan suap telah menjadi kebiasaan dalam kehidupan umat Israel, sehingga para pemimpin mereka yaitu para hakim yang bertugas sebagai pemimpin politik maupun pemimpin keagamaan juga telah jatuh ke dalam kebiasan suap-menyuap. Hal ini berbanding terbalik dengan sosok Samuel yang berhasil menjalankan tugasnya sebagai hakim, di mana pada akhir pengabdiannya, secara tegas ia menentang orang Israel dan mengatakan ketidakterlibatannya dalam persoalan suap dan sogok, seperti yang dapat kita baca dalam I Sam. 12:3 "Lembu siapakah yang telah kuambil? Keledai siapakah yang telah kuambil? Siapakah yang telah kuperas? Siapakah yang telah kuperlakukan dengan kekerasan? Dari tangan siapakah telah kuterima sogok sehingga aku harus tutup mata?". Sikap sebagai hakim yang adil dan jujur seperti Samuel yang tidak menerima suap dan sogok ini, juga mendapat penekanan ketika Raja Yosafat (Yehuda: 870-848) mengangkat para hakim yang bertugas untuk mengadili dan memutuskan perkara di semua kota Yehuda, sambil berpesan: “...Bertindaklah dengan seksama, karena berlaku curang, memihak ataupun menerima suap tidak ada pada Tuhan, Allah kita" (2 Taw.19:7).

Persoalan suap dan sogok di kalangan para hakim ini semakin kuat terjadi tatkala Israel menjadi sebuah kerajaan, khususnya ketika mereka mengalami masa-masa kemakmuran sekitar abad ke VIII SM, yang memunculkan kritik kenabian terhadap keadaan tersebut, seperti yang disampaikan oleh nabi Yesaya, Amos dan Mikha.

Nabi Yesaya (berkarya di kerajaan Israel Selatan (Yehuda) sekitar tahun 740-700 SM, khususnya pada masa pemerintahan raja Ahaz, 736-716 (proto Yesaya: psl.1-39; Darmawijaya, 1990:85,86), melihat dan mengkritik praktek-praktek suap dan sogok yang terjadi di kalangan para pemimpin umat Israel (Yehuda): "para pemimpinmu adalah pemberontak dan bersekongkol dengan pencuri. Semuanya suka menerima suap dan mengejar sogok". Mereka tidak membela hak anak-anak yatim, dan perkara janda-janda tidak sampai kepada mereka" (Yes.1:23). Kenyataan bahwa para pemimpin umat tidak melaksanakan kewajiban mereka dalam membela hak anak-anak yatim dan tidak menangani perkara para janda dikarenakan mereka menerima suap dan sogok. Bahkan karena suap yang mereka terima tersebut, maka kebenaran yang harus mereka tegakkan ternyata diputarbalikkan; Orang fasik mereka benarkan, sedangkan hak orang benar mereka pungkiri (Yes. 5: 23). Semakin parahnya praktek suap dan sogok di kalangan Israel, sampai-sampai ketika Yesaya menyampaikan berita penghukuman dari Tuhan Allah, ia menyampaikan bahwa orang yang dapat terbebas dari malapetaka yang mengerikan antara lain, “Orang ... yang mengebaskan tangannya, supaya jangan menerima suap...” (Yes.33:15). Sementara orang yang terlibat suap dan sogok tidak akan luput dari malapetaka yang akan ditimpakan Tuhan Allah. Jelaslah bahwa Yesaya sangat keras menentang praktek suap dan sogok di kalangan pemimpin Israel, karena 
Allah sendiri tidak menghendaki dan menentang praktek suap dan sogok, tetapi menghendaki keadilan dan kebenaran dalam proses peradilan, dan membela hak anak-anak yatim dan perkara para janda. Mereka yang terlibat praktek suap dan sogok tidak akan luput dari hukuman Allah.

Pada zaman nabi Amos (berkarya di Kerajaan Israel Utara sekitar tahun 760-750 BC. Ia berasal dari desa Tekoa (sebuah dusun di Israel Selatan), tetapi menyampaikan warta kenabiannya di Israel Utara, terutama di sekitar tempat ibadah Bethel dan barangkali juga di Samaria; Banawiratma, ed., 1987:62-63), kerajaan Israel Utara ditandai oleh kemakmuran yang luar biasa. Di kalangan masyarakat kelas atas, kenyataan itu menumbuhkan semangat konsumeristis, puas diri, penurunan semangat beragama, dan permisif dalam bidang moral, dan seperti biasa, juga muncul penindasan terhadap rakyat kecil. Dalam keadaan itulah muncul Nabi Amos. Ia melihat kemakmuran itu hanya sebagai kesempatan untuk terjadinya korupsi (suap, sogok) dan berbagai ketidakadilan struktural lainnya: "Sebab Aku tahu, bahwa perbuatanmu yang jahat banyak dan dosamu berjumlah besar, hai kamu yang menjadikan orang benar terjepit, yang menerima uang suap dan yang mengesampingkan orang miskin di pintu gerbang" (Am.5:12).

Dalam seruan itu, Amos mengecam praktek suap yang sering terjadi pada proses peradilan di pintu gerbang, yang merugikan kepentingan orang benar dan miskin. Menerima uang suap dinilai sebagai perbuatan yang jahat dan dosa, menimbulkan ketidakadilan. Praktek suap yang menimbulkan ketidakadilan bukanlah semata-mata perbuatan buruk terhadap sesama manusia (alasan sosial), melainkan terutama tindakan buruk terhadap Allah (alasan teologis) (Banawiratma, ed. 1987:66). Allah selalu menentang ketidakadilan dan berpihak kepada orang yang miskin dan yang tertindas. Maka dapat dimaklumi bahwa Allah sendiri akan menghukum tindakan tersebut seperti yang disampaikan Amos dalam 5:11 (bnd. 2:13; 4:2). Tetapi Amos juga mewartakan keselamatan yang disediakan Allah bagi mereka yang mau bertobat: "carilah yang baik dan jangan yang jahat, supaya kamu hidup" (5:14), yakni dengan jalan "menegakkan keadilan di pintu gerbang" (5:15b), dengan tidak menerima suap dan memutuskan perkara secara adil pada saat proses peradilan di pintu gerbang.

Nabi Mikha (berkarya di Kerajaan Israel Selatan (Yehuda) sekitar tahun 725701 BC (Darmawijaya, 1990:107), berasal dari desa Moresyet, seperti halnya Yesaya, juga melihat kecurangan dan kegagalan para pemimpin Yehuda (Israel Selatan): "para kepalanya memutuskan hukum karena suap, dan para imamnya memberi pengajaran karena bayaran, para nabinya menenung karena uang,..." (Mikha 3:11). Hukum yang mestinya diputuskan secara adil oleh para pemimpin Israel, ternyata diputarbalikkan menjadi ketidakbenaran dan ketidakadilan karena mereka menerima suap. Di jaman Mikha, kemerosotan moral di kalangan umat Israel terjadi di mana-mana seperti yang dikatakan dalam psl.7:1-6, juga antara lain "tangan mereka sudah cekatan berbuat jahat; pemuka menuntut, hakim dapat disuap; pembesar memberi putusan sekehendaknya, dan hukum, mereka putar balikkan!” (ay.3). Karena perbuatan mereka tersebut, maka Mikha menyampaikan berita penghukuman dari Allah seperti dalam 3:12. Itu berarti bahwa Mikha juga sama seperti halnya nabi-nabi lain, melihat suap bukan hanya perbuatan buruk terhadap sesama (alasan sosial), tetapi juga terhadap Allah (alasan teologis), dan karena itu Allah akan menghukum pelaku perbuatan tersebut. 
Penentangan PL terhadap praktek suap dan sogok ini tidak saja disuarakan di kalangan para nabi, tetapi juga dalam kumpulan mazmur dan tradisi hikmat. Dalam kumpulan mazmur misalnya, disebutkan bahwa orang yang boleh menumpang dalam kemah Allah, dan yang boleh diam di gunung Allah yang kudus (15:1), antara lain yaitu "dia yang ... tidak menerima suap melawan orang yang tak bersalah..."(15:5). Itu berarti, orang yang menerima suap dipandang tidak layak di hadapan Allah, sedangkan dalam Maz. 26:10, disebutkan bahwa "orang yang tangan kanannya menerima suapan" disamakan dengan orang berdosa dan penumpah darah (ay.9).

Dalam tradisi hikmat, juga terdapat penekanan tentang suap. Amsal mengajarkan orang yang membenci dan tidak menerima suap akan hidup, “...tetapi siapa membenci suap akan hidup" (Ams.15:27). Itu berarti bahwa orang yang menginginkan kehidupan adalah orang yang membenci dan tidak menerima suap. Dalam kitab Ayub, diceritakan bahwa Ayub sebagai pribadi yang saleh tidak pernah berkata: "... berilah aku uang suap dari hartamu”(Ay.6:22). Tetapi bagi orang yang menerima suap, “...api akan memakan habis kemah-kemah orang yang makan suap" (Ay.15:34). Kisah Ayub mengajarkan bahwa orang yang saleh adalah orang yang tidak menerima suap, sedangkan orang yang menerima suap akan mengalami malapetaka.

Dari berbagai penjelasan tentang pandangan PL terhadap perilaku korupsi (suap) seperti yang telah diuraikan di depan, kita dapat menarik beberapa kesimpulan:

a. Perilaku korupsi (suap) mendapat perhatian hampir dalam seluruh PL: dalam kitab-kitab Taurat, zaman pra-kerajaan, zaman kerajaan, zaman pembuangan, dan juga di dalam kitab-kitab mazmur dan tradisi hikmat di Israel. Hal ini menegaskan bahwa masalah suap bukanlah masalah yang hanya disoroti sepintas lalu, tetapi merupakan salah satu masalah pokok yang disoroti dalam PL selain pokok pergumulan lainnya.

b. Penilaian dan kritikan PL terhadap praktik suap tidak saja berdasarkan alasan sosial, yaitu karena suap merugikan orang banyak, tetapi terlebih berdasarkan alasan/motif teologis di mana suap berhubungan dengan sifat dan karakter Allah yang tidak menerima suap. Sifat dan karakter Allah yang tidak dapat disuap inilah yang mewarnai PL dalam mengkritisi praktik suap di Israel.

c. Dalam PL, praktik suap sangat berhubungan dengan proses peradilan. Akibat praktik suap keadilan diputarbalikkan, dan orang yang benar apalagi yang lemah dan yang miskin selalu dikorbankan. Hal ini tentu tidak sejalan dengan kehendak Allah yang menghendaki ditegakkannya keadilan dan selalu berpihak kepada orang yang miskin dan lemah dalam memperjuangkan keadilannya.

d. Praktik korupsi yang disoroti dalam PL lebih disebabkan oleh adanya penyalahgunaan jabatan, khususnya jabatan hakim dalam proses peradilan. Jabatan yang mestinya dilakukan demi kebenaran dan keadilan, ternyata digunakan untuk kepentingan (memperkaya) diri sendiri.

e. PL secara tegas menyatakan penghukuman Allah terhadap para pelaku suap. Penghukuman Allah tersebut selalu disampaikan ketika PL mengkritisi perilaku suap. Penghukuman Allah tersebut tidak hanya berlaku kepada para pelaku suap (pemimpin Israel), tetapi akibat dari perbuatan mereka tersebut, seluruh bangsa Israel 
f. Walaupun berita penghukuman Allah telah disampaikan, tetapi masih ada keselamatan yang disediakan Allah bagi mereka yang mau bertobat dari perilaku suap tersebut (bnd. pesan nabi Amos).

\section{Perjanjian Baru}

Dalam Perjanjian Baru (PB), persoalan korupsi kurang mendapat sorotan jika dibandingkan dengan PL. Hal ini mungkin disebabkan oleh keadaan sosio-politik dan pemerintahan di zaman PB berbeda dengan zaman PL. Keadaan sosio-politik dan pemerintahan pada zaman PL di mana Israel masih berbentuk kerajaan atau memiliki pemerintahan sendiri untuk beberapa waktu lamanya, sehingga berbagai perilaku korupsi di kalangan pemimpin Israel zaman itu akan langsung mendapat sorotan dan kritikan dari para nabi maupun tulisan lainnya. Sedangkan keadaan sosio-politik pada zaman PB, umat Israel tidak lagi memiliki pemerintahan sendiri karena sudah menjadi wilayah taklukan dan jajahan kekaisaran Romawi. Karena itu, berbagai kebijakan penguasa Romawi yang korup tidak terlalu menjadi perhatian dari para penulis $\mathrm{PB}$, Mereka lebih cenderung untuk mengkritisi dan membina kehidupan umat zaman PB. Walaupun demikian, masih ada beberapa perilaku korupsi dalam PB yang dapat kita temui sekaligus mencoba mendapatkan pandangan PB terhadap praktik korupsi. Memang, praktik-praktik yang kita temui dalam PB ini tidak secara tegas menyebutkannya sebagai praktik korupsi. Namun, kalau dinilai lebih mendalam, praktik-praktik tersebut juga merupakan praktik korupsi dan mendapat kecaman dalam PB. Praktik-praktik korupsi tersebut dapat kita lihat sebagai berikut:

a. Korupsi di kalangan para pemungut cukai dan prajurit Romawi (Lukas 3:1-20)

Dalam Luk. 3:1-20, penulis Injil Lukas menghadirkan cerita tentang pekerjaan Yohanes Pembaptis (paralel dengan Mat. 3:1-12 dan Mark. 1:1-8). Hal yang membedakan cerita tentang Yohanes dalam Injil Lukas dengan kedua Injil lainnya adalah dialog dalam Luk. 3:10-14, yang tidak terdapat di dalam kedua Injil tersebut. Dalam ayat-ayat sebelumnya (7-9), sama halnya dengan Matius (3:7-9), keduanya memuat perkataan Yohanes yang menuntut pertobatan hidup dari para pendengarnya saat itu. Tetapi penulis Injil Lukas tidak hanya menuntut pertobatan dari mereka, mereka juga harus menghasilkan bukti nyata dari pertobatan tersebut, seperti yang ditegaskan dalam beberapa dialog tambahan antara Yohanes dengan para pendengarnya (ay.10-14). Penulis Lukas secara khusus menampilkan dialog antara Yohanes dengan para pemungut cukai dan para prajurit. Atas pertanyaan para pemungut cukai: "Guru, apakah yang harus kami perbuat?" (ay.12), Yohanes menjawab: "Jangan menagih lebih banyak dari pada yang telah ditentukan bagimu" (ay.13), dan untuk pertanyaan yang sama dari para prajurit, Yohanes menjawab: "Jangan merampas dan jangan memeras dan cukupkanlah dirimu dengan gajimu" (ay.14). Yohanes tidak bermaksud agar mereka melepaskan jabatannya tersebut, tetapi mereka harus melepaskan "dosa-dosa jabatan" mereka (Boland, 2003:83), yaitu dosa-dosa yang secara khusus berhubungan dengan jabatan mereka. Penulis Lukas lewat cerita Yohanes ini memintakan para pembacanya untuk meninggalkan kebiasaan memungut lebih banyak dari yang sudah ditetapkan di kalangan para pemungut cukai, dan kebiasaan menyalahgunakan kekuasaan di kalangan para prajurit untuk merampas dan memeras rakyat (Esler, 1987:197). F.W. Danker (dalam Hendriks, 1990: 22) memberikan penilaian terhadap dialog ini sbb.: "... kapak menyerang sistem dengan tiba-tiba. Jangan menagih lebih banyak daripada yang telah ditentukan 
bagimu. Kata-kata yang sederhana ini menembus akar korupsi, mencari keuntungan, dan semua jerat yang mengulur untuk menghancurkan kesehatan, hakikat, akhlak serta kekuatan moral seorang individu maupun bangsanya ... Pemunculan para prajurit dalam kisah, langsung sesudah para pegawai pemungut cukai, memberi kesan bahwa kekuatan militer dalam kombinasi dengan sistem-sistem penindasan, menjadi sasaran tuduhan khusus.

Dialog antara Yohanes dengan para pemungut cukai dan prajurit Romawi ini ditampilkan secara khusus oleh penulis Lukas paling tidak sebagai kritik dan koreksi terhadap praktik korupsi dan ketidakadilan yang terjadi pada zaman itu, baik secara umum di wilayah kekaisaran Romawi, maupun secara khusus di wilayah Palestina. Praktik korupsi yang begitu meluas di wilayah kekaisaran Romawi dan telah menguasai berbagai bidang: pengadilan, angkatan perang, dunia usaha, Senat, pergantian kaisar, sistem pemilihan, sistem tuan hamba, pemerintahan, bahkan juga rakyat Romawi, ternyata juga tergambar dalam dialog Yohanes ini, khususnya di kalangan pemungut cukai (semacam pegawai pabean yang bekerja untuk pemerintah Romawi) dan para prajurit (angkatan perang) Romawi. Praktik korupsi di kekaisaran Romawi ternyata tidak saja terjadi di level atas (kaisar, wali negeri, pengadilan, Senat), tetapi juga di level bawah yakni di kalangan pemungut cukai dan prajurit Romawi. Masyarakat kecil yang berada di wilayah kekaisaran Romawi pada zaman itu, pastilah menghadapi berbagai ketidakadilan akibat diterapkannya sistem pajak yang memberatkan karena praktik korupsi oleh para pemungut cukai, dengan cara menagih lebih daripada apa yang seharusnya mereka tagih, dan pemerasan yang dilakukan oleh para prajurit Romawi.

Kelebihan sebagai hasil korupsi dari tagihan tersebut tentu dapat digunakan untuk memperkaya diri mereka, sehingga para pemungut cukai pada umumnya termasuk golongan yang kaya. Pekerjaan sebagai pemungut cukai ini penuh dengan penyalahgunaan. Fakta ini dapat kita temukan misalnya dalam cerita tentang Zakheus (Luk.19:110), di mana Zakheus merupakan seorang yang kaya dari pekerjaannya sebagai seorang kepala pemungut cukai. Dalam cerita tersebut, Lukas memunculkan suatu pengakuan dari Zakheus sehubungan dengan pekerjaannya itu: "Tuhan.... sekiranya ada sesuatu yang kuperas dari seseorang akan kukembalikan empat kali lipat" (ay. 8). Akibat dari pengakuan Zakheus yang menunjukkan pertobatannya dari tindakan pemerasan (korupsi) yang dilakukannya selama ini, Yesus menyatakan: "Hari ini telah terjadi keselamatan kepada rumah ini...." (ay. 9). Dalam pandangan Yesus, tindakan Zakheus ini tidak salah, ia dibenarkan dan menemukan keselamatan disediakan Yesus (Esler, 1987: 195). Jelaslah bahwa bagi penulis Injil Lukas masih tersedia pengampunan dan keselamatan di dalam Yesus bagi para koruptor yang mau bertobat dan mau meninggalkan perbuatan korupsinya. Terlepas dari ada tidaknya pemerasan yang dilakukan oleh Zakheus, namun dari pernyataannya ini jelas bahwa pekerjaan sebagai pemungut cukai tersebut mengandung risiko terjadinya penyalahgunaan jabatan berupa praktik korupsi dalam bentuk pemerasan karena cukai yang dipungut dapat melebihi apa yang sudah ditetapkan, apa yang seharusnya. Itulah sebabnya, maka pekerjaan sebagai pemungut cukai ini dipandang sebagai pekerjaan yang rendah dan dibenci oleh masyarakat dan pemuka-pemuka agama pada saat itu, bahkan para pemungut cukai ini dipersamakan dengan 'orang berdosa', seperti yang dikatakan dalam ayat 7: "Ia menumpang di rumah orang

berdosa"

(bnd.

Luk.

5:30). 
Kita dapat menyimpulkan bahwa korupsi yang dilakukan oleh para pemungut cukai dan prajurit ini bersifat multi-sebab, yaitu disebabkan oleh sifat ketamakan dalam diri mereka, atau karena kurangnya gaji yang mereka peroleh. Selain itu, juga disebabkan oleh lemahnya sistem pengontrolan terhadap mereka, yang menyebabkan mereka mendapatkan dan memiliki kesempatan untuk melakukan korupsi, menyalahgunakan jabatan yang ada pada mereka untuk memperkaya diri sendiri.

Kasus Yudas Iskariot (Yohanes 12:1-8)

Dalam Injil Yohanes (12:1-8), penulis menampilkan pribadi Yudas Iskariot sebagai seorang koruptor. Diceritakan bahwa Yesus diurapi oleh Maria (saudara Lazarus dan Marta) dengan minyak narwastu yang mahal harganya. Cerita ini juga terdapat di dalam Mat. 26:6-13 dan Mrk. 14:3-9. Cerita yang membedakannya adalah reaksi (negatif) terhadap peristiwa tersebut. Dalam Injil Matius, reaksi terhadap tindakan Maria tersebut datang dari para murid (Mat. 26:8,9), dan dalam Injil Markus reaksinya datang dari orang banyak (Mrk. 14:4,5), sedangkan dalam Injil Yohanes, reaksi negatif terhadap tindakan Maria itu datang dari Yudas Iskariot. Terhadap tindakan Maria yang meminyaki Yesus, Yudas mengatakan: "mengapa minyak narwastu ini tidak dijual tiga ratus dinar dan uangnya diberikan kepada orang-orang miskin?" (ay.5). Jumlah uang sebanyak tiga ratus dinar tersebut menjadi perhatian Yudas, sebab jumlahnya tidak sedikit. Satu dinar sama dengan upah pekerja biasa selama satu hari (Mat. 20:2), sehingga tiga ratus dinar hampir sama dengan gaji selama satu tahun. Alasan yang dikemukakan oleh Yudas ini cukup logis dan dapat diterima apalagi jika uang yang banyak itu hendak digunakan untuk menolong orang miskin. Tetapi, penulis Injil Yohanes lalu menambahkan: "hal itu dikatakannya bukan karena ia memperhatikan nasib orangorang miskin, melainkan karena ia adalah seorang pencuri, ia sering mengambil uang yang disimpan dalam kas yang dipegangnya." (ay.6). Ternyata pernyataan Yudas tersebut menurut penulis Injil Yohanes bukanlah menunjukkan perhatian dan kepeduliannya yang sungguh kepada nasib orang-orang miskin, tetapi faktanya bahwa ia adalah seorang pencuri. Yudas merupakan pemegang kas, seorang bendahara di antara muridmurid Yesus. Dengan adanya ketersediaan uang dalam kas yang dipegangnya, menjadi kesempatan kepada Yudas untuk mencuri uang tersebut bagi kepentingannya sendiri. Singkatnya, Yudas adalah seorang koruptor.

Dari cerita Yudas dalam Yoh. 12:1-8 tersebut, kita dapat menyimpulkan bahwa seorang bendahara (pemegang kas) dapat tergoda untuk menggunakan jabatannya tersebut bagi kepentingan dirinya sendiri. Sekalipun bendahara tersebut adalah seorang yang dekat dan 'bergaul' dengan Tuhan, seorang yang mengetahui kehendak Tuhan seperti halnya Yudas Iskariot, namun ia tidak luput dari godaan jabatannya. Jabatan itu terus menggoda Yudas, sehingga jika ada kesempatan, ia akan melakukan korupsi.

Kasus Ananias dan Safira (Kis. 5:1-11)

Jika dalam Lukas 3:1-20, kita telah melihat praktik korupsi yang terjadi di kalangan para pemungut cukai dan prajurit, yakni mereka yang merupakan orang luar dari komunitas Kristen mula-mula maka dalam kasus Ananias dan Safira (Kis. 5:1-11) kita dapat melihat contoh kasus korupsi yang terjadi di kalangan orang dalam dari 
komunitas Kristen mula-mula. Perlu diingat bahwa penulis Kisah Para Rasul adalah juga penulis Injil Lukas. Dalam kasus Ananias dan Safira ini, penulis Kisah Para Rasul menceritakan bahwa keduanya menjual sebidang tanah dan bersekongkol untuk menahan sebagian dari hasil penjualan itu, dan sebagiannya lagi dibawa kepada para rasul (ay.1,2). Tindakan kedua orang ini, menurut Stott (1990:109), menunjukkan bahwa mereka telah melakukan dosa ganda (a double sin), yaitu ketidakjujuran (dishonesty) dan penipuan (deceit). Sesuai dengan cara hidup jemaat saat itu yang digambarkan oleh penulis dalam Kis. 4:32-37, segala sesuatu adalah kepunyaan mereka bersama, mereka menjual kepunyaannya dan hasil penjualan tersebut mereka serahkan semuanya kepada rasul-rasul untuk dibagikan kepada setiap orang sesuai dengan keperluannya, seperti yang telah dilakukan oleh Barnabas. Tetapi Ananias dan Safira ternyata tidak melakukan hal yang demikian. Mereka menahan sebagian dari hasil penjualan tanah mereka dan menyerahkan sebagiannya lagi kepada para rasul.

Dengan melakukan tindakan itu, Ananias dan Safira telah melakukan kesalahan berupa penggelapan yang menunjukkan ketidakjujuran mereka. Ketidakjujuran tersebut menunjukkan kemunafikan mereka seperti kata Petrus dalam ay. 3-4. Dengan perbuatan Ananias dan Safira yang menahan sebagian hasil penjualan tanah itu, menurut Petrus keduanya tidak saja mendustai manusia, tetapi lebih dari itu, mereka mendustai Roh Kudus atau Allah. Ketidakjujuran dan kemunafikan (kebohongan) Ananias dan Safira merupakan perbuatan dosa, sehingga mereka harus menerima akibat perbuatan mereka tersebut, keduanya mati seketika itu juga (ay. 5,10).

Dari cerita tentang Ananias dan Safira dalam Kisah Para Rasul 5:1-11 ini, kita dapat menyimpulkan bahwa tindakan penyelewengan (korupsi) yang dilakukan oleh Ananias dan Safira merupakan tindakan yang mementingkan diri sendiri (egoisme) dan tidak mementingkan kepentingan orang banyak. Penyelewengan ini berakar pada adanya niat di dalam hati mereka, yakni hati yang dikuasai oleh Iblis (ay.3), sehingga mereka mendustai Roh Kudus (Allah), dengan menahan sebagian dari hasil penjualan tanah itu. Perbuatan mereka itu ternyata tidak saja mendustai manusia tetapi lebih dari itu mendustai Allah (ay. 4). Dapat dikatakan bahwa korupsi adalah perbuatan Iblis yang telah menguasai hati manusia, manusia telah bersekutu dengan Iblis sehingga manusia tersebut melakukan korupsi yang melawan sifat dan kehendak Allah yang tidak korup. Akibat dari perbuatan itu, Ananias dan Safira mengalami penghukuman Allah, di mana keduanya mati seketika itu juga. Hal ini menunjukkan bahwa segala perbuatan yang tidak sesuai dengan kehendak Allah, apalagi yang mendustai Allah, jika tidak disadari dan diikuti dengan pertobatan (kesempatan tersebut ada pada Safira!) akan mengalami penghukuman Allah. Ananias dan Safira mengalami penghukuman Allah akibat mendustai Allah. Manusia yang mendustai Allah dengan mengikat persekutuan dengan Iblis pada hakikatnya adalah manusia yang telah terpisah dan berada di luar persekutuan dengan Allah, manusia yang telah mati dan berada di bawah penghukuman Allah.

Ketiga contoh yang telah dipaparkan di atas, kiranya dapat menjadi gambaran bagi kita untuk memahami perspektif PB tentang korupsi. Beberapa hal yang dapat kita kemukakan sehubungan dengan perspektif PB terhadap korupsi ini adalah:

a. Korupsi dapat terjadi karena adanya dorongan atau niat dari dalam diri (hati) koruptor (Ananias-Safira). Dorongan atau niat hati ini disebabkan oleh hati korup- 
tor tersebut telah dikuasai dan dipengaruhi oleh Iblis untuk melakukan korupsi. Korupsi jelas merupakan perbuatan Iblis dalam diri manusia. Tetapi korupsi juga dapat terjadi karena adanya dorongan dari luar, adanya peluang yang dapat dimanfaatkan oleh koruptor untuk melakukan korupsi. Para pemungut cukai dan prajurit memiliki peluang untuk korupsi karena jabatan yang mereka miliki, serta lemahnya kontrol terhadap jabatan tersebut. Sedangkan jabatan Yudas sebagai bendahara memberikan peluang untuknya melakukan korupsi.

b. PB secara tegas menentang praktik korupsi. Korupsi tidak saja menipu manusia, tapi lebih dari itu, mendustai Allah/Roh Kudus (dalam kasus Ananias dan Safira). Karena korupsi tersebut merupakan perilaku yang mendustai Allah, hukuman Allah telah tersedia bagi para koruptor.

c. PB tidak hanya menyatakan penghukuman Allah terhadap para koruptor, tetapi juga menyatakan kemurahan dan keselamatan yang disediakan Allah bagi para koruptor yang mau bertobat. Setelah Zakheus menyatakan pertobatannya, Yesus berkata: "Hari ini telah terjadi keselamatan kepada rumah ini".

\section{Pandangan para Teolog: Manusia itu Korup}

Para teolog, dalam memberikan penilaian terhadap perilaku korupsi, umumnya lebih menaruh perhatian pada penyebab (akar) korupsi. Akibat-akibat korupsi tidak menjadi perhatian para teolog, karena akibat korupsi hanyalah merupakan kulit, bagian luar dari persoalan korupsi dan bukan persoalan utama (inti) korupsi. Mengapa manusia itu korup, itulah pertanyaan yang dijawab oleh para teolog. Jawaban atas pertanyaan ini juga yang menurut para teolog akan menjadi entry point upaya pencegahan dan pemberantasan praktik korupsi. Para teolog umumnya menilai penyebab korupsi berasal dari faktor internal manusia. Korupsi bermula dari dalam diri manusia itu sendiri. Statusnya sebagai orang berdosa menyebabkan manusia itu korup, dan senantiasa melakukan perbuatan yang merusak (korup) dalam kehidupannya. Korupsi yang dipahami oleh para teolog ini adalah korupsi moral, yakni kehidupan moral manusia yang telah korup (rusak) akibat dosa. Pendapat beberapa teolog akan dikemukakan di sini.

\section{a. Augustinus}

Augustinus memberikan pandangannya terhadap manusia sebagai makhluk yang telah rusak (korup) dalam perdebatannya dengan kaum Pelagian. Kaum Pelagian meyakini bahwa sekalipun manusia itu berdosa, kehendak manusia pada hakikatnya baik dan mampu memilih secara bebas, dosa Adam hanya merusak dirinya dan bukan keturunannya, dosa itu turun kepada angkatan berikutnya bukan karena diwariskan tetapi karena ditiru (Calvin, 1989:214). Mereka menolak apa yang diyakini oleh para Bapa Gereja sebagai Dosa Asali atau Dosa Warisan (Original Sin). Augustinus menanggapi pandangan kaum Pelagian ini, dengan berpendapat bahwa kita tidak rusak oleh keburukan yang kita ambil dari orang sekitar kita, tetapi kerusakan itu kita bawa sejak dari rahim ibu. Augustinus menegaskan bahwa kodrat yang kita wariskan telah rusak (korup) "because the nature which begets is corrupt" (Calvin, 1989:216). Perbuatan buruk di dalam diri manusia menurut Augustinus, termasuk di dalam dirinya semata-mata disebabkan oleh dosa yang ada di dalam dirinya, sebagai keturunan Adam. Karena Dosa Asali tersebut maka semua manusia yang adalah keturunan Adam telah rusak (korup), dan hanya Tuhan Allah yang tidak dapat mengalami kerusakan (incorrupt- 
ible), apa pun keadaan-Nya (Calvin, 1989:161).

Bagi Augustinus, kehendak bebas (the free will decision) di dalam diri manusia merupakan penyebab manusia itu berbuat jahat. Augustinus menyatakan bahwa kehendak bebas di dalam dirinya untuk melakukan apa yang ia inginkan atau tidak inginkan, merupakan penyebab dosanya. Manusia dengan kehendak bebasnya untuk memilih yang baik dan yang jahat ini diibaratkan oleh Augustinus seperti kuda yang ditunggangi oleh Allah atau Iblis. Karena itu, tergantung pada manusia tersebut sendiri untuk memperhatikan isyarat yang mengendarai kehidupannya, Allah atau Iblis dengan berbagai konsekuensinya. Jika ia menghendaki hidupnya itu baik, ia harus memperhatikan isyarat dari Allah, tetapi jika ia mendengar isyarat dari Iblis, maka hidupnya akan rusak (Calvin, 1989:266).

Lebih lanjut menurut Augustinus, Allah begitu mengasihi manusia sehingga Ia tidak membiarkan manusia itu hancur. Allah berkenan memperbaiki keberadaan manusia yang telah rusak tersebut. Kasih sayang (mercy) Allah yang besar itu telah dinyatakanNya dengan berkenan memberikan FirmanNya (Yesus Kristus) menjadi daging dan diam di antara manusia, dan anugerah (grace) Allah tersebut ditujukan kepada orang-orang yang rendah hati (Calvin, 1989:167). Bagi Augustinus, Allah di dalam AnakNya Yesus Kristus berkenan membuka jalan keselamatan kepada kehidupan yang akan datang bagi manusia. Karena itu, Augustinus menegaskan bahwa anugerah Allahlah yang mendahului pekerjaan yang baik pada manusia dan manusia hanya memiliki kemauan untuk melakukan yang baik mengikuti dan menuruti anugerah Allah, bukan memimpin atau mendahului anugerah Allah tersebut (Calvin, 1989:256). Penegasan Augustinus ini didasarkan pada ajaran Alkitab yang menggambarkan sukacita di surga dan di dunia jika orang yang berdosa bertobat dan diselamatkan. Allah menurut Augustinus, tidak berkenan manusia menemui kebinasaannya, tetapi melalui anugerahNya di dalam Yesus Kristus, Allah berkenan menyediakan keselamatan bagi manusia yang telah rusak (korup). Keselamatan itu diperoleh melalui pengampunan dan hidup kekal dengan jalan pertobatan dan menanggapi anugerah dan kemurahan Allah dengan rendah hati, juga memberikan hidupnya dituntun oleh Roh Kudus.

John Calvin

Calvin secara luas menjelaskan bagaimana manusia yang korup ini. Seperti Augustinus, Calvin menilai bahwa manusia itu korup (rusak) berawal dari Dosa Asali/ Turunan (Original Sin) yang diwarisi manusia sebagai keturunan Adam (Calvin, 1989:256). Bagi Calvin, dosa yang dilakukan oleh Adam mengakibatkan ia mengalami keterpisahan dengan Allah. Keterpisahan itu menyebabkan Adam menanggung hukumannya, yakni kematian jiwa dan berbagai penderitaan lainnya. Namun bukan hanya Adam yang menanggung resiko dari perbuatannya. Akibat pemberontakannya itu, seluruh tertib alam semesta juga menjadi rusak. Bahkan akibat dosa Adam itu, seluruh keturunan Adam ikut terjerumus ke dalam berbagai penderitaan. Jadi menurut Calvin, yang disebutkan oleh para Bapa Gereja dengan Dosa Asali adalah membusuknya kodrat yang pada mulanya baik dan murni.

Calvin (1989:219), mengemukakan bahwa manusia yang rusak (corrupt) bukan disebabkan oleh kodratnya (nature) dan oleh suatu subtansi pada diri manusia sejak awal, tetapi disebabkan karena kejahatan (natural viciousness) yang menyebabkan kejatuhannya. Lebih lanjut, dijelaskan oleh Calvin bahwa awal kerusakan Dosa Asa- 
li adalah pada diri Adam, kemudian mewariskan kerusakan (korup) tersebut terusmenerus dari orangtua kepada anak-anak dan cucu-cucu mereka. Hal itu diibaratkan oleh Calvin dengan akar yang busuk (korup), yang menghasilkan cabang-cabang yang busuk pula lalu menyebarkan kebusukan tersebut ke semua rantingnya.

Dosa turunan didefinisikan oleh Calvin (1989:217) sebagai "a hereditary corruption and depravity of our nature,...", suatu kerusakan dan kebejatan pada kodrat kita yang bersifat turun-temurun. Kerusakan (korup) pada diri manusia oleh dosa tersebut menurut Calvin telah menguasai seluruh jiwa manusia, termasuk pikiran, hati, dan kemauannya. Manusia yang telah rusak (korup) oleh kejatuhannya tersebut selalu terdorong untuk melakukan yang jahat oleh kemauan dan nafsunya sendiri, bukan karena sesuatu dari luar. Begitu buruknya kodrat manusia tersebut sehingga ia tidak dapat berbuat yang lain kecuali melakukan yang jahat. Karena itu, bagi Calvin, manusia memang tidak bisa tidak harus berdosa. Calvin menunjuk pada kutipan Paulus dalam Roma 3:10, "Tidak ada yang benar, seorang pun tidak." Dengan mengutip ayat ini, Calvin maksudkan tidak hanya supaya manusia itu bertobat, tetapi lebih dari itu untuk mengajarkan bahwa semua orang akan ditimpa oleh malapetaka, dan karena itu mereka hanya dapat dibebaskan dari malapetaka tersebut "by the mercy of God." (Calvin, 1989:250).

Hanya kasih sayang (mercy) dan anugerah (grace) Allah, menurut Calvin, yang dapat menjadi obat untuk memperbaiki dan menyembuhkan kerusakan (korup) kodrat manusia akibat dosa. Manusia dapat melakukan kebenaran hanya jika hatinya dibentuk, diarahkan dan diperkuat oleh Allah. Calvin mengingatkan kita bahwa di tengah-tengah kerusakan (korup) kodrat itu masih ada suatu tempat bagi anugerah Allah, bukan untuk membersihkan kerusakan tersebut, melainkan untuk mengendalikannya (Calvin, 1989:251). Melalui pemeliharaanNya (providence), Allah mengendalikan kodrat manusia yang rusak (korup) tersebut sedemikian rupa, sehingga kerusakan tersebut tidak terwujud dalam perbuatan manusia yang dipelihara oleh Allah tersebut. Hanya Allah sajalah yang dapat memperbaiki manusia yang telah rusak.

\section{Robert Borrong}

Menurut Robert Borrong, dalam perspektif etika, manusia pada hakikatnya adalah korup: "kecenderungannya adalah korup dan karena itu tingkah lakunya juga korup. Segala perbuatannya yang korup, didorong oleh hati nuraninya yang memang korup. Singkatnya, pribadi manusia adalah korup. Akibat dosa, hakekat manusia memang korup." (Borrong, 1983:150). Korupsi bukan akibat melainkan hakikat dari manusia itu sendiri, dan telah menjadi kecenderungannya. Karena itu, korupsi bagi Borrong pertama-tama merupakan penyakit dalam, penyakit yang berakar dalam jiwa manusia, jiwa yang rusak akibat dosa, akibat keakuan (egois) dan kesombongannya. Ini merupakan dasar yang hakiki dari korupsi. Manusia yang korup itu lalu dikendalikan oleh keserakahan akan materialisme dan dorongan berkuasa, yang saling melengkapi.

Karena itu, untuk memberantas korupsi, maka menurut Borrong (2006:106), dari sudut pandang moral hal itu harus dikaitkan dengan pembinaan manusia sebagai makhluk yang disembuhkan dan diselamatkan oleh rahmat Tuhan. Sikap pertama yang dituntut dari seorang koruptor adalah pertobatan (metanoia). Artinya meninggalkan hidupnya yang bergelimang dosa dan mengakui kemurahan Tuhan yang mampu memperbarui, menyucikan dan menguduskan hidupnya. Dengan demikian terjadi pencabu- 
tan akar korupsi yaitu dengan jalan mengubah manusia berdosa yang egois dan sombong menjadi manusia bersyukur dan rendah hati. Untuk itu, yang diperlukan dalam memberantas korupsi bukan saja pemberlakuan hukum formal tetapi terutama ditimbulkannya kesadaran akan kesalahan pada para koruptor. Sekalipun hukum ditegakkan tetapi jika para koruptor tidak memiliki kesadaran moral, maka mereka tak punya rasa bersalah dan karena itu mereka akan kembali melakukan korupsi.

\section{Rangkuman}

Dari berbagai penjelasan terhadap perilaku korupsi yang telah diuraikan baik dari perspektif Alkitab (PL dan PB) maupun beberapa pandangan teolog, kita dapat membuat beberapa catatan rangkuman:

1. Etika Kristen secara tegas menolak dan mengkritik praktik korupsi. Korupsi sebagai perbuatan buruk dan yang merugikan banyak orang tidak dapat diterima dan merupakan perbuatan yang tidak etis.

2. Penolakan etika Kristen terhadap korupsi ini tidak hanya bersumber dari akibat sosial yang ditimbulkan olehnya (korupsi merugikan banyak orang), melainkan dari sifat dan karakter Allah yang tidak dapat disuap (korup).

3. Dalam etika Kristen, manusia melakukan korupsi disebabkan oleh sifat dan hakikatnya sebagai makhluk yang telah rusak (korup) akibat dosa. Korupsi terjadi karena hati manusia dikuasai dan dikendalikan oleh Iblis, karena itu korupsi merupakan perbuatan Iblis. Manusia tidak dapat melakukan sesuatu yang baik karena ia telah rusak (korup), kecuali hidupnya dikuasai dan dibimbing oleh Allah melalui RohNya yang berkuasa di dalam hati manusia tersebut.

4. Karena praktik korupsi merupakan perbuatan dosa dan melanggar kehendak Allah maka telah tersedia penghukuman Allah bagi para koruptor. Korupsi bukan saja merupakan persoalan manusiawi (sosial) sehingga para koruptor akan mengalami hukuman duniawi, yakni melalui hukum negara, melainkan lebih dari itu korupsi merupakan persoalan religius (teologis). Dengan demikian para koruptor akan bertanggung jawab dan akan dihakimi oleh Allah.

5. Tetapi di samping penghukuman Allah tersebut, masih ada anugerah dan pengampunan Allah yang tersedia bagi para koruptor yang mau bertobat. Allah di dalam Yesus Kristus telah menyatakan kasih dan anugerahNya untuk menyelamatkan orang berdosa termasuk para koruptor, jika koruptor tersebut mau bertobat dan membuka diri menyambut keselamatan tersebut. Hanya anugerah Allah di dalam Yesus Kristus yang dapat mengobati dan menyembuhkan keadaan manusia yang telah rusak (korup) tersebut.

6. Untuk memberantas praktik korupsi, maka dari perspektif etika Kristen, faktor moral harus mendapat prioritas utama. Faktor moral inilah yang merupakan penyebab (akar) korupsi, karena itu moral manusia mesti dibina terlebih dahulu, yaitu dengan mengubah keberadaan manusia tersebut sebagai manusia berdosa yang egois dan sombong menjadi manusia yang bersyukur dan rendah hati. 


\section{Penutup}

Perilaku korupsi dalam perspektif Etika Kristen ini hendak memperhadapkan kehendak Allah kepada kita, yakni menjauhi praktek korupsi sebab tidak saja merugikan masyarakat (dampak sosial), tetapi juga bertentangan dengan kehendak Allah (dimensi teologis-etis). Perspektif ini kiranya memberikan kepada kita kekuatan dan tanggung jawab moral dalam menghadapi berbagai praktek korupsi yang disebabkan oleh lemahnya institusi/aturan (adanya kesempatan), maupun karena adanya berbagai isme yang mendorong kita untuk melakukan tindakan korupsi tersebut (adanya niat).

Semoga tulisan ini bermanfaat bagi setiap kita......

“FIDES PROCEDIT INTELLECTUM” (Iman mendahului pengertian). 


\section{KEPUSTAKAAN}

\section{Buku}

Alatas, S.H. Sosiologi Korupsi. Jakarta: LP3ES, 1983.

Alatas, S.H. Korupsi: sifat, sebab dan fungsi. Jakarta: LP3ES, 1987.

Bagiyowanadi, F.X. Didik, Pr. Mengikis Budaya Korupsi. Yogyakarta: Yayasan Pustaka Nusatama, 2003.

Banawiratma, J.B, SJ. (editor). Gereja dan Mayarakat. Yogyakarta: Penerbit Kanisius, 1987, Cetakan ke-2.

Birch, Bruce C. Let Justice Roll Down (The Old Testament, Ethics, and Christian Life). Louisville: Wesminster/John Knox Press, 1991.

Boland, B.J. Tafsiran Alkitab: Kitab Injil Lukas. Jakarta: BPK Gunung Mulia, cet. ke-8 2003.

Borrong, R.P. Citra Umum Korupsi. Thesis Magister Teologi pada STT Jakarta, 1983. . Etika Politik Kristen: Serba-serbi Politik Praktis. Jakarta: UPI \& PSE STT Jakarta, 2006.

Brownlee, Malcolm. Tugas Manusia dalam Dunia milik Allah. Jakarta: BPK Gunung Mulia, 2004, Cetakan ke-5.

Calvin, John, Institutes of the Christian Religion (Translated by: Henry Beveridge), Grand Rapids: Wm. B. Eerdmans Publishing, 1989.

Darmawijaya, St. Warta Nabi Abad VIII. Jakarta: Penerbit Kanisius, 1990.

Esler, Philip Francis. Community and Gospel in Luke-Acts. New York: Cambridge University Press, 1987.

Guthrie, Donald. New Testament Theology (terjemahan Lisda Tirtapraja Gamadhi dkk, dengan judul: Teologi Perjanjian Baru 3). Jakarta: BPK Gunung Mulia, 2003, Cetakan ke-8).

Hendriks, Herman. Keadilan Sosial dalam Kitab Suci. Yogyakarta: Kanisius, 1990.

Houlden, J.L. Ethics and The New Testament. Edinburgh: T \& T Clark, 1992.

Klitgaard, Robert. Controlling Corruption (terjemahan Hermoyo dengan judul: Membasmi Korupsi). Jakarta: Yayasan Obor Indonesia, 2001, Cet. Ke-2. 
Klitgaard, Robert. Dkk, Corrupt Cities (terjemahan Masri Maris dengan judul: Penuntun Pemberantasan Korupsi). Jakarta: Yayasan Obor Indonesia, 2002.

Kostenberger, Andreas J. John (Baker Exegetical Commentary on the New Testament). Grand Rapids, Michigan: Baker Academic, 2004.

Lubis, Mochtar dan James C. Scot. (penyunting). Korupsi Politik. Jakarta: Yayasan Obor Indonesia, 1993. . (penyunting). Bunga Rampai Korupsi. Jakarta: LP3ES, 1995, Cet. Ke-3.

Napel, Henk ten. Jalan Yang Lebih Utama Lagi (Etika PB). Jakarta: BPK Gunung Mulia, 2001, Cetakan ke-6.

Perum Percetakan Negara RI. Percepatan Pemberantasan Korupsi. Jakarta: Perum PNRI, 2004.

Prent, K cm dkk. Kamus Latin-Indonesia. Semarang: Penerbit Kanisius, 1969.

Pusat Bahasa Departemen Pendidikan Nasional. Kamus Besar Bahasa Indonesia. Jakarta: Balai Pustaka, 2001.

Sairin, Weinata. Iman Kristen dan Pergumulan Kekinian. Jakarta: BPK Gunung Mulia, 1996.

Stott, John R. W. The Message of Acts. Leicester: Inter-Versity Press, 1990.

Tanja, Victor I. Spiritualitas, Pluralitas dan Pembangunan di Indonesia. Jakarta: BPK Gunung Mulia, 1996.

Wright, Christopher. Living as the People of God (terjemahan oleh Liem Siem Kie dengan judul: Hidup Sebagai Umat Allah). Jakarta: BPK Gunung Mulia, 1993).

\section{Jurnal/Majalah}

Equilibrium (jurnal Ekonomi dan Kemasyarakatan). Vol.2, No.3. Problem ekonomi-politik: Utang sampai Korupsi, Sep-Des 2004.

Proklamasi (jurnal Teologi STT Jakarta). Edisi No.3/Th.2/Februari 2003. 